\author{
СПЕЦИФІКА ТЕАТРАЛЬНОЇ | Сорока Марина Василівна \\ ІНСЦЕНІЗАЦІї ТВОРІВ Кандидат мистеитвознавства, \\ В. ВИННИЧЕНКА НАПРИКІНЦІ ORCID: 0000-0002-0509-8508, \\ XX - ПОЧАТКУ XXI CT. e-mail: marysya-@ukr.net, \\ Київський національний університет \\ культури і мистеитв, \\ вул. Свгена Коновальия, 36, Київ, Україна, 01133
}

\begin{abstract}
Мета статті - розглянути театральну інсценізацію творів В. Винниченка в українському театрі наприкінці $\mathrm{XX}$ - початку XXI ст. Методологія дослідження полягає у використанні аналізу, синтезу та логічного узагальнення. Зокрема, під час контент-аналізу квантифікували п’єси В. Винниченка й інтерпретували концептуально-художні пошуки театральних діячів. Тематичний аналіз ювілейних публікацій, наукових досліджень та рецензій на п’єси засвідчив значну увагу національного театру до проблематики творів В. Винниченка. Наукова новизна полягає в аналізі режисерських втілень п’єс В. Винниченка «Чорна Пантера і Білий Ведмідь», «Гріх» та «Брехня» на українській сцені, а також у порівнянні вистави «Гріх» різних епох (Г. Юри і М. Горохова). Висновки. З'ясовано, що на початку 1990-х років XX століття п’єси В. Винниченка привертали увагу багатьох українських митців. Водночас режисерські втілення подекуди неочікувано дивували. Виявлено, що найбагатшу сценічну історію 3-поміж усіх творів письменника мають п’єси «Чорна Пантера і Білий Ведмідь», «Гріх» та «Брехня». Вистави Г. Юри і М. Горохова за п’єсою «Гріх» мають як подібні риси, так й істотно різняться. Зокрема, обидва режисери за основу обрали моральний аспект, у якому виділили три позиції спільного і відмінного: ціннісні оріснтації - ідеал; позиція - умови — вибір; відповідальність — проступок - кара. Наголосимо, що найбільш переконливого й цілісного втілення п’єси В. Винниченка набули у постановках А. Бабенко. Режисерка, застосовуючи нововведення, насичує вистави символізмом і створює образ швидкоплинності людського життя та вічності мистецтва. Доведено, що постановки п’єс В. Винниченка наочно засвідчують, що в українській драматургії і театральному мистецтві зростає особистісне начало, а вистави набувають ознак ідеологічної драми. Сьогодні актуально сприймається нагальна потреба відновлювати історично перевірені обставини й ситуації, висвітлюючи об’єктивні процеси розвитку театрального мистецтва в Україні.
\end{abstract}

Ключові слова: В. Винниченко; п’єси; режисер; театр; культура; художні пошуки

\title{
Вступ
}

В. Винниченко належить до плеяди національних митців, які зробили значний внесок у всеукраїнський культурний поступ, інтегруючи його у світовий. Увійшовши в українську культуру на початку $\mathrm{XX}$ ст. - у добу духовного перевороту, «бунту індивідуальності» - письменник зажив слави порушника канонів, збурювача спокою. Своїми творами В. Винниченко відгукнувся на потребу оновлення репертуару українського театру, що переживав на той час своєрідну жанрову кризу, одним із чинників якої була етнографічно-побутова заангажованість української драматургії.

Аналіз останніх досліджень $і$ публікаиій. Загальному розумінню творчої спадщини, поетики, парадоксів драматургії В. Винниченка сприяли роботи В. Гуменюка (2001), А. Гурбанської (2020), Д. Гузар-Струка (1994), М. Жулинського (1993), Ю. Коваліва (2001), Г. Костюк (1980), Л. Мороз (1994), В. Панченка (2004), В. Селіванової (2001) та ін. Наголосимо, що в УРСР творчість В. Винниченка фактично була під забороною, а спроби шістдесятників реабілітувати В. Винниченка й повернути його творчість українському народові закінчилися репресіями і від 1970 року згадки про нього траплялися лише в публікаціях самвидаву. На сьогодні «величезна й багатогранна творчість та громадська його діяльність в багатьох аспектах є для нас загадкою» (Костюк, 1980).

Зі здобуттям Україною незалежності раніше замовчувана в часи тоталітаризму спадщина В. Винниченка стала предметом грунтовного літературознавчого осягнення. На думку В. Панченка, «серед нереалізованих творчих задумів Володимира Винниченка - «Роман мого життя», власне — автобіо-

$\overline{\text { (C) Сорока M. B., } 2021}$ 
графія, яка мала всі шанси стати захопливим життєписом, адже доля цього українського письменника i державного діяча виявилася надзвичайно щедрою на авантюрні сюжети - любовні, психологічні, політичні» (Панченко, 2004).

Важливою частиною спадщини В. Винниченка $є$ п’єси, які відразу привертали увагу театральних діячів та понад століття інтерпретувалися на сценах різних театрів. Зокрема, В. Гуменюк дослідив провідні риси поетики драматургії письменника та на основі художнього аналізу його п’єс простежив творчу еволюцію Винниченка-драматурга, визначив iï етапи (Гуменюк, 2001). Актуальність творчості письменника проявляється й у тому, що у його творах «йдеться про ті проблеми, які є спільними для художників усіх часів і всіх народів» (Мороз, 1994, с. 94). Метадраматизм, сценографію, режисерські трактування п’єс В. Винниченка у постановках українських театрів досліджували Г. Веселовська (2010), О. Вісич (2019), П. Кравчук (1999, 2008).

Дослідження художнього тлумачення літературної спадщини В. Винниченка в українському театрі й кіно наприкінці XX - у перших двох десятиліттях XXI ст. продовжують визначати експеримент, пошуки нових сценічних форм, індивідуальну стилістику режисерів, акторів, сценографів та інших діячів цих сфер мистецтва, а також динаміку культурно-мистецького руху загалом.

Наукова новизна полягає у аналізі режисерських втілень п’єс В. Винниченка «Чорна Пантера і Білий Ведмідь», «Гріх» і «Брехня» на українській сцені, а також у порівнянні вистави «Гріх» різних епох (Г. Юри і М. Горохова).

\section{Мета статті}

Мета статті - розглянути театральну інсценізацію творів В. Винниченка в українському театрі наприкінці XX - початку XXI ст.

Методологія дослідження полягає у використанні аналізу, синтезу та логічного узагальнення. Зокрема, під час контент-аналізу квантифікували п'єси В. Винниченка та інтерпретували концептуально-художні пошуки театральних діячів України у зв'язку з історико-культурними умовами та мистецькими тенденціями часу. Тематичний аналіз ювілейних публікацій (Рибалко, 2018), наукових досліджень (Гринишина, 2012; Липківська, 2012) та рецензій на п’єси «Брехня», «Гріх» А. Головки (А. Г., 1921а, 1921b), А. Вечерницького (1911), В. Сімовича (1911) засвідчив значну увагу національного театру до проблематики творів В. Винниченка, інтригуючи глядачів художніми експериментами у сфері людської моралі й спонукаючи до пошуку істини та гармонії в сучасному світі.

\section{Виклад матеріалу дослідження}

Сучасний розвиток театрального мистецтва в Україні свідчить про пильну увагу до п’єс В. Винниченка.

Творчість В. Винниченка, схильного до філософствування, зокрема до логічного обгрунтування будь-якого кроку людини, розпочалася на зламі двох культурно-стильових епох (кін. XIX - поч. XX ст.), у час глобальної перебудови мистецьких зображально-виражальних систем, викликаних потребою в нових засобах, здатних сприяти інтенсивному осягненню внутрішнього світу людини.

У його творах тісно переплелися українська та європейська традиції з новими естетичними віяннями, що значною мірою зумовило проблематику, типологію конфліктів, сюжетно-образні особливості та своєрідність індивідуальної стильової манери. За визначенням Л. Мороз (1994): «Змістову суть творчості В. Винниченка складають болісні роздуми над невідповідністю ідеалу дійсності, спостереження неймовірної складності людини — як істоти соціальної й водночас безмежного індивідуаліста, — здатної на безоглядну самопожертву й шалений егоцентризм» (с. 15).

Драматургія В. Винниченка (психологічні п’єси «Дисгармонія» (1906), «Momento» (1907), «Базар» (1910), «Брехня» (1910), «Чорна Пантера і Білий Ведмідь» (1911), «Натусь» (1912), «Гріх» (1918) та ін.) присвячена дослідженню людської особистості, морально-психологічних випробувань і внутрішніх сил людини в боротьбі за утвердження власного «я» (екзистенційні мотиви: особисті стосунки та соціальні відносини, родина та інтимний світ жінки, проступок і кара, талант і ціна його реалізації), розвивалася в річищі модерних літературних течій, зокрема новітніх тенденцій європейської драми п’єс К. Гауптмана, Г. Ібсена, М. Метерлінка, А. Чехова й ін., а в українській — Лесі Українки.

3-поміж усіх драматичних творів В. Винниченка найбагатшу сценічну історію, мабуть, має п'єса «Чорна Пантера і Білий Ведмідь». Розмірковуючи про широке звернення театрів до творчості В. Вин- 
ниченка, М. Жулинський вказує, що «чи не найбільший успіх випав на долю п’єси «Чорна Пантера і Білий Ведмідь», підтверджуючи цей факт висловом Г. Костюка: «Ні одна п’єса, ні одного українського драматурга за всю історію української літератури не може похвалитись такою сценічною біографією» (Костюк, 1983, с. 23). «Чорну Пантеру...» ставили також театри Німеччини, Італії, Норвегії, Румунії, Росії, Іспанії, Хорватії, Данії, Швеції і Сербії. Крім того, у Німеччині за драмою В. Винниченка зняли один із перших фільмів німого кіно.

За твердженням А. Липківської (2012): «найбільш адекватного, переконливого й стилістично цілісного втілення «декадентські» п’єси В. Винниченка набули у постановках Алли Бабенко, режисера цілком «жіночого» світогляду, але «по-чоловічому» твердої руки» (с. 71). Наприклад, 20 квітня 1990 р. на сцені Національного академічного українського драматичного театру імені М. Заньковецької з'являється вистава за п’єсою В. Винниченка «Чорна Пантера і Білий Ведмідь» режисерки Алли Бабенко. Роль Корнія, Білого Ведмедя, виконував молодий актор С. Глова, Рити, Чорної Пантери - Л. Кадирова, Сніжинки - Л. Боровська, а роль Мулена - Б. Козак.

Щоб скерувати психотерапевтичний ефект п’єси на реципієнта-глядача, А. Бабенко вдалася до умовно-символічного обрамлення. Так, у виставу режисер увела умовну постать П'єро. Своєрідний епіграф вистави - «живе фото», яке зібрало всіх дійових осіб для промовляння ключових для постановника слів із тексту твору: «Мистецтво повинно відображати все, а передусім життя і страждання людей», «Митець не має нації. Насамперед - форма. Що таке форма?», «Одне мистецтво має вічність». Сцену по великому колу оформили величезними рамами, які для акторів були і вікнами, і дверима. У такий спосіб художниця Л. Боярська створила динамічну сценографію.

Рецензенти, які дивилися виставу в різних містах України (Харків, Одеса, Дніпро та ін.), із усіх зайнятих у ній акторів відзначали майстерну, а подекуди філігранну гру Л. Кадирової і висловлювали певні претензії до гри іiї партнера С. Глови, наголошуючи, що старання щосили - це ще не ключове у створенні завершеного образу. 3 інших акторів високу оцінку отримала гра Б. Козака (Мулен) і Є. Федорченка в ролі Янсона. Загалом відзначався непересічний професіоналізм львівської трупи. Висловилися вони також і з приводу пластично-просторового та музичного оформлення постановки. Відзначили витонченість та доречність музики у виставі, її звучання за подібністю чи контрастом до психічного стану героя. Зауважили, що оформлення вистави ефективно доповнювало головну ідею.

Режисерські нововведення А. Бабенко, зокрема поява нового персонажа П'єро, а також прийом «живого фото», критики теж схвалили. Саме ці нововведення надали виставі більшого символізму: по спорожнілій сцені йде-бреде сумний П'єро - дух Мистецтва, з подивом зупиняється перед останнім твором Білого Ведмедя і промовляє поетичні рядки Аполлінера про минущість людського життя і вічність мистецтва.

У тому ж 1990 р. твір «Чорна Пантера і Білий Ведмідь» поставили у Львівському обласному театрі ім. Я. Галана у Дрогобичі (режисер Я. Бабій). Вистава викликала надто багато запитань, зокрема, чому другу дію з артистичної кав'ярні перенесено до ательє Корнія, адже це значно зміщує акценти з особи Корнія та його дружини. Герої вистави постали як виражено агресивні люди, які виправдовують свої прізвиська Пантери й Ведмедя і мало не гарчать одне на одного. Очевидно, що і режисер, і актори виявилися дуже далекими від непростих філософських та етичних проблем, якими переймався В. Винниченко. Поза увагою творчого колективу залишилися стосунки митця із суспільством — його сім'я, питання відповідальності за свої вчинки перед іншими, міра залежності таланту від суспільства, питання свободи й ін. Театр належно не заглибився в змістовні глибини Винниченкової драми, вдовольнившись сферою інтимних, сімейних стосунків.

21 жовтня 1992 р. режисерка А. Бабенко поставила «Чорну Пантеру...» на малій сцені Харківського державного академічного українського драматичного театру ім. Т. Г. Шевченка. Ролі виконували: Корній - Ю. Головін, Рита - I. Кобзар, Сніжинка - Л. Платонова, Мулен - П. Рачинський. Художник вистави - Т. Медвідь.

Образ Корнія втілив актор Ю. Головін, який інтерпретував свого героя як м'якого, доброго, інтелігентного, природно неконфліктного чоловіка, проте й такого, який здатний на жахливі $з$ погляду здорового глузду слова і вчинки, абсолютно не розуміючи їхнього блюзнірства. Рецензенти відзначали, що найбільше досягнення Ю. Головіна у вмінні змусити глядачів співчувати таким проявам, до яких люди не звикли й не повинні співчувати. Простежувалася думка про егоїстичного, жорстокого, взагалі нестерпного чоловіка, батька і сина, якого не треба засуджувати за звичними законами співжиття. Для гри I. Кобзар (Чорна Пантера) в пластичному рішенні ролі притаманний якийсь «вишукано-декадентський вивих», для пластики Л. Платонової (Сніжинки) — «королівська величність». 
На початку 1990-х рр. й особливо зі здобуттям Україною незалежності, вистави за п'єсами В. Винниченка почали з'явилися на сцені Кіровоградського обласного (нині - академічного) українського музично-драматичного театру ім. М. Л. Кропивницького. Повертаючи В. Винниченка землякам, у 1991 р. режисер театру Микола Горохов поставив «Ідею пані Мусташенко» за драмою «Закон» (прем'єра вистави відбулася 27 березня), а 24 листопада 1992 р. — вистави «Гріх». Обидві постановки частина глядачів сприйняли щиро, частина - насторожено. Із цими виставами театр кілька років успішно гастролював у Черкасах і Полтаві, неодноразово брав участь у святах театрального мистецтва, зокрема у фестивалі «Вересневі самоцвіти» (Кіровоград, «Хутір Надія»).

Прикметно, що перед прем'єрою вистави «Гріх» у Кіровоградському обласному краєзнавчому музеї відбулося відкриття експозиції «Володимир Винниченко. Повернення». Завдяки співпраці комісії Верховної Ради України з питань культури і духовного відродження, українсько-американського фонду «Відродження», ЮНЕСКО й організаційній діяльності народного депутата першого складу Верховної Ради України В. Панченка, із Франції (м. Мужен) для експонування у Кіровоградському музеї, надійшла унікальна колекція, а саме: меморіальні речі В. Винниченка (торбинка з українською землею, прижиттєві видання творів, кілька картин, фотокопії, годинник, меблі, посуд, письмове приладдя, друкарська машинка, настільна лампа й ін.).

У новітній інтерпретації «Гріха» режисер-постановник Микола Горохов, актори, сценограф Павло Босий виходили з глибокого розуміння, що драматургія В. Винниченка істотно відрізняється від традиційної української драми, що за художніми вимірами вона складна й багатогранна: у плані сюжетно-образного ряду (низка подій, стосунки між героями) п'єса має один зміст, на рівні філософської й моральної проблематики - інший, на рівні психіки людини - ще інший, чому її ставити (режисерам), грати в ній ролі (акторам) і дивитися іiі (глядачам) непросто, але в усіх трьох вимірах дуже цікаво. Власне гармонійне поєднання всіх рівнів драматургії В. Винниченка, постановки театрального дійства та сприйняття глядачів викликає високу естетичну насолоду, співпереживання, ефект катарсису (очищення душі від бруду буднів), що є покликанням справжнього мистецтва.

Осмислення проблеми гріха в драмі В. Винниченка і на сцені театру імені М. Л. Кропивницького визначено в такому дискурсі: що таке гріх?; яка межа відділяє людину від проступку непоправного?; чи можна спокутувати зраду, коли вона вчинена заради порятунку інших, навіть коханої людини? 3 приводу цих питань сперечаються персонажі, цими питаннями вимірюються їхні вчинки, подібними думками переймаються глядачі.

У рецензіях на постановку кропивничанами «Гріха» відзначається високий рівень сценічного втілення Винниченкових образів - i індивідуальних авторських робіт, i ансамблю вистави загалом. Центральний у п’єсі та виставі образ Марії Ляшківської яскраво відтворила Н. Іванчук, а образ жандармського підполковника Сталинського, з яким увійшла у трагічний конфлікт головна героїня, майстерно створив заслужений артист України А. Романюк.

На відміну від постановок Г. Юри, здійснених у 1920-х роках, М. Горохов на передній план виводить не образ жандарма Сталинського, а зрадниці Марії - жінки, яка страждає за своє відчайдушне кохання; «в основу іiї образу покладено «архетипний образ Єви - жінки-спокусниці. Цей факт відсилає нас до біблійної оповіді, згідно з якою Єву спонукає до гріха диявол» (Сорока, 2016, с. 58). С. К'єркегор у праці «Страх і тремтіння» розглядає положення про те, що жінка чуттєвіша за чоловіка, а відповідно - більше підвладна страху (Кьеркегор, 1993, с. 174). Отже, у виставі кропивничан за драмою В. Винниченка «Гріх» тріада персонажів «Марія - Сталинський - Іван» проєктується на біблійну тріаду «Єва - диявол - Адам». Виходячи із к'єркегорівської тези про більшу чуттєвість жінки і підвищену рефлективність їі страху, глядачеві в цьому контексті стає особливо чітко зрозумілим, чому Сталинський-диявол спокушає до зради саме Марію, а не Івана. Марія співпрацює зі Сталинським «за страх»; до гріхопадіння (зради своїх) героїню спонукає саме він: жінка боїться за життя коханого.

Сценограф вистави П. Босий згадує: «неймовірної потужності акторський дует Наталії Іванчук і Анатолія Романюка примушував мене мимоволі забувати про те, що я саме зараз у театрі, на сцені, роблю свою справу, та занурюватися у таємничий світ підсвідомості автора і його героїв. На кожній репетиції я відчував, неначе я бачив цих героїв уперше» (Босий, б.р., с. 174).

Привернула увагу глядачів і досконала гра інших акторів, завдяки якій запам'ятовуються другорядні образи: Олена Карпівна — стара діва і святенниця (артистка Є. Мельниченко), Ангелок робітник-друкар (артист О. Дорошев), студент Михась - сором'язливий, але відданий справі юнак (артист Д. Полетаєв), його батько Середчук, до відчаю стривожений долею свого єдиного сина, який 
став підпільником (артист П. Онищенко), особливо Ніздря - морально покалічений жандармський приспішник, котрий ще здатний на жест людяності (артист С. Козир).

Майстер сценічної дії В. Винниченко вмістив у свої п’єси, зокрема і в драму «Гріх», розлогі ремарки 3 детальними описами обставин і характеристиками персонажів: у розгорнутих передмовах він роз'яснює акторам, читачам, глядачам власне бачення зображуваного, як-от в останній ремарці: «Марія плаче. Потім виймає з шухляди столу слоїк, іде з ним до дзеркала, дивиться, чепуриться... Потім рішуче підносить слоїк до вуст. Завіса» (Винниченко, 1991, с. 534).

Сценографія вистави, виконана П. Босим, стримана, проте виразна. У центрі сцени - високі балконні двері, за якими видніються освітлені бані собору. Така деталь, не передбачена автором драми, стала вдалою театральною знахідкою: собор створює сценічний образ святості, яку так непросто втримати в душі серед веремії гріха. Цей образ проникає у світогляд самого В. Винниченка: бувши атеїстом, як соціаліст, у глибині душі він зберігав вірність християнським моральним постулатам.

Режисерську майстерність М. Горохова визначили його тонкий естетичний смак, смілива здатність вступати в суперечку із традиціями та із самим автором, що засвідчує, зокрема, фінал, несхожий на авторський. Марія, попередивши товаришів про небезпеку і зважившись прийняти отруту, з розкинутими, як розп'яття, руками, прямує крізь балконні двері до собору. Усвідомивши свій гріх - зраду, вона приймає найстрашнішу спокуту - смерть, проте на сцені не падає мертвою, а стоїть на фоні собору, що теж символічно.

Загалом же летальні фінали в п’єсах В. Винниченка, а відтак і в їхніх сценічних інтерпретаціях, трапляються часто, оскільки модельовані автором ситуації морального експерименту «провокували» саме такий кінець. Водночас вони пояснюються світоглядом письменника: у глибині душі він зберігав вірність християнським моральним постулатам, що й увиразнили у виставі театру імені М. Л. Кропивницького.

П'єса «Гріх» і вистави за нею, подібно до інших, наочно засвідчують, як в українській драматургії і в театральному мистецтві зростає особистісне начало (на тлі особистих трагедій постають неповторні людські долі й характери), як твори і вистави за ними набувають ознак ідеологічної драми, оскільки трагічний пафос постає через драму ідей (діалоги - словесні дуелі, напружені монологи, сповнені глибоких душевних мук, та ін.). У цьому зв'язку сьогодні актуально сприймається нагальна потреба відновлювати перевірені обставини й ситуації, висвітлюючи об'єктивні процеси розвитку театрального мистецтва в Україні.

Стосовно ж зіставлення спектаклів Г. Юри і М. Горохова за п’єсою «Гріх», на нашу думку, є всі підстави стверджувати, що за основу обоє режисерів обрали моральний аспект. Вважаємо за доцільне виділити три позиції спільного і відмінного різних постанов і різних епох: ціннісні орієнтації — ідеал; позиція - умови — вибір; відповідальність - проступок - кара. Розмаїття концептуально-художніх пошуків театральних діячів України у зв'язку з історико-культурними умовами та мистецькими тенденціями часу засвідчують зростання уваги національного театру до проблем основ і сутності життя, людської гідності і свободи вибору, оновлення його сценічних форм, інтригуючи глядачів художніми експериментами у сфері людської моралі й спонукаючи до пошуку істини та гармонії в сучасному світі.

У березні 1991 р. на сцені Національного академічного українського драматичного театру імені М. Заньковецької режисер А. Бабенко ставить п’єсу «Брехня». Головну роль у виставі виконала нині вже народна артистка України, лауреат Шевченківської премії Л. Кадирова. Пізніше в одному зі своїх інтерв’ю А. Бабенко зазначить: «А коли стала самостійна Україна, кинулись до Винниченка. Винниченко - це мій автор» (Бабенко, 2004). Режисерка додала у виставу дещо своє, те, чого не було в тексті твору. Сцена самогубства головної героїні проходить двічі. Спершу Наталія Павлівна розігрує своє самогубство і дивиться на реакцію оточення, а потім, побачивши як вони зреагували, робить це вдруге, але вже по-справжньому, хоча інші персонажі вважають, що це жарт. Л. Кадирова називала такий фінал вистави «потрясаючим».

Провідним елементом створення Л. Кадировою образу Наталії Павлівни була «абсолютна жіноча самотність». А. Бабенко володіла майстерністю вибудовування діалогів, і глядачі точно усвідомлювали причини дії. Вистава у стилі «сецесії» починалася декораціями й костюмами і закінчувалася пластикою персонажів. Особливо відверто в цьому стилі працювала головна героїня п'єси. Загалом вистава підпорядковувалася стилістиці «мерехтливої естетики», яку сповідували режисер А. Бабенко й актриса Л. Кадирова.

Відомо, що виставу возили на Чехівський фестиваль, де серед глядачів був відомий співак Іван Козловський. Артиста настільки вразила вистава, що одразу після іiі завершення він вийшов на сцену, 


\section{СЦЕНІЧНЕ МИСТЕЦТВО}

ISSN 2410-1176 (Print) • Вісник КНУКіМ. Серія: Мистецтвознавство. Вип. 45 • ISSN 2616-4183 (Online)

подарував А. Бабенко чорну хлібину зі свічками і 20 хвилин піднесено характеризував постановку «Брехні». Російський драматург М. Рощин теж високо оцінив виставу. Театрознавець С. Веселка зазначила, що в п’єсі «Брехня» Лариса Кадирова показала «не знаний глядачами 1990-х років тип української інтелігентної жінки. Розумної, витонченої, з мінливо-мерехтливою красою духовних імпульсів, безумовністю жіночої привабливості» (Веселка, 2003). Слушним є висновок А. Карась: вистава А. Бабенко була просякнута «духом відродження, постання з попелу, повільного, кропіткого збирання... Вона не належить до беззастережних та яскравих перемог, які одразу й усіх переконують у власній правоті... Вистава львів'ян являє собою ту кропітку та покірливу домашню роботу, яку зроблено взапас, складено до весни» (Карась, 1992).

У 1992 р. Київський державний академічний театр драми і комедії на лівому березі Дніпра перший у незалежній Україні поставив виставу В. Винниченка «Брехня». У російськомовному, на той час, театрі вистава була дивиною. Вона започаткувала двомовність театру, хоча навіть нині, у час майже 30-літньої незалежності України, багато вистав в українському державному театрі йдуть іноземною, російською мовою. Режисером вистави був колишній учень художнього керівника театру О. Балабан. Так сталося, що рецензій на виставу не збереглося. Нам відомо, що вона демонструвалася лише кілька разів і була знята з показу художнім керівником Е. Митницьким. Сьогодні на офіційному сайті театру виставу «Брехня» режисера О. Балабана називають «сенсаційною».

У 1993 р. інтерпретацію драми В. Винниченка «Брехня» крізь призму ідеї «чесності з собою» та внутрішнього конфлікту головної героїні Наталії Павлівни здійснив у Дніпропетровському українському музично-драматичному театрі ім. Т. Г. Шевченка режисер М. Волошин. Оригінальною «родзинкою» вистави стало те, що вона розпочинається й завершується філософською сентенцією Карпа Федоровича - батька головного героя Андрія Карповича, в домі якого розгортаються події, про безмір людини й любові. На думку літературного й театрального критика В. Марка, зміст сентенції, не властивий Винниченковій п’єсі, спрямовує виставу в єдине філософське річище в той час, як автор зображує життя та людину в ньому на різних рівнях (Марко, б.р., с. 116). «Із таким режисерським прийомом можна дискутувати. Далі вистава пройшла $з$ дотриманням авторського тексту і на високому професійному рівні», висловлюється ще один глядач вистави, літературознавиця і критикеса А. Гурбанська (2015, с. 140). Маємо всі необхідні підстави стверджувати, що режисерські пошуки М. Волошина у використанні свіжих сценічних форм та образів пояснюються його тонким естетичним смаком, сміливою здатністю вступати в суперечку з традиціями та із самим автором, що засвідчує, зокрема, початок, несхожий на текст літературного твору.

Виставу за драмою В. Винниченка «Брехня» у Дніпропетровському українському музичнодраматичному театрі ім. Т. Г. Шевченка поставили в контексті художнього вираження драматургом його ідей філософії щастя як сенсу й мети людського існування, в основі яких «закон погодження взаємоелементів буття» (В. Винниченко) - здоров'я, розуму, кохання та ін. Виставу можна розглядати як певний експеримент з аналітичної антропології, покликаний зафіксувати своєрідну кризу запропонованого «закону погоджень»; у ній реалізується художньо закладена діалектичність, суперечливість цієї філософської теорії.

Події відбуваються в родині інженера-винахідника Андрія Карповича (артист - А. Шевченко), в одному й тому ж інтер'єрі, проте це не створює монотонності на сцені: внутрішня динаміка вистави стрімка, словесні поєдинки бурхливі, а сповіді-одкровення персонажів настільки відверті та часом несподівані, що глядачі перебувають у стані зачарованості.

На сцені розгортається сімейна драма, традиційний любовний «трикутник», який доповнює «четвертий кут». Наталія Павлівна (артистка - О. Волошина), дружина Андрія Карповича, який завершує довготривалу роботу зі створення оригінального мотора, має молодого коханця — поетично обдарованого студента Антона Михайловича (артист - С. Дрожаков), котрого ніжно називає Тосем, «Котиком», «Вогником». Ситуація ускладнюється тим, що в господиню закоханий і помічник Андрія Карповича, теж інженер, Іван Стратонович, який, підслухавши емоційні розмови коханців і нечесним шляхом здобувши Тосеві листи до Наталії Павлівни, погрожує віддати їх Андрію Карповичу; ба більше, виявляється, що Наталія Павлівна теж кохає Івана Стратоновича. Такий перший - сюжетний, подієвий — план вистави. Зовнішні стосунки між персонажами супроводжуються морально-етичним, філософським, психологічним планами.

Ситуаційним, психологічним, моральним центром вистави, як і в драмі В. Винниченка, є образ Наталії Павлівни. Відповідно і всі інші герої пов'язані з нею: усі висловлюють власне ставлення до Наталії Павлівни, відверто чи приховано спонукають ії до певних учинків. О. Волошина в ролі Ната- 
лії Павлівни постає перед глядачем у двох іпостасях: з одного боку, вона турботлива дружина (дбає про здоров'я чоловіка, приватними уроками допомагає йому прогодувати велику родину), невістка, яка обожнює свого свекра, прийняла двох його дочок, до яких також добре ставиться; з іншого боку, вона має приховане життя. Кохання Наталії Павлівни артистка переконливо виражає в трьох аспектах: як кохання-жалість, свідому самопожертву (визначає ï̈ ставлення до чоловіка); як романтичне кохання, яке доповнює материнська любов (поєднання любовних почуттів у стосунках із Тосем); як кохання-стихію, «демонічну» силу (взаємини з Іваном Стратоновичем). Як слушно наголошує Л. Мороз (1994): суть цього твору - «одного $з$ найзагадковіших у світовій драматургії - полягає в тому, що в межах його незмінного тексту героїню можна трактувати в багатьох, відмінних один від одного, аспектах, — втім, як і інших персонажів, - саме тому, що п’єса містить багато отих локальних, конкретних істин». I наостанок дослідниця додає: «Утім, це стосується більшості п’єс Винниченка» (с. 104).

Напруження глядачів вистави зростає з наближенням трагічної розв'язки, коли розмови про лавро-вишневі краплі (у прямому розумінні - ліки, а в змові Наталії Павлівни та Івана Стратоновича - отрута) частішають, віщуючи трагедію. Відбувається сатанинська гра: Іван Стратонович все наполегливіше штовхає Наталію Павлівну на останній крок, хоча насправді не бажає ій смерті.

До глибини душі глядача вражає фінальна сцена, коли Андрій Карпович та Іван Стратонович святкують перемогу (їхня робота прийнята фірмою-замовником, і вони мають отримати солідну винагороду), а Наталія Павлівна, немовби захмелівши від келиха шампанського, цілується з усіма присутніми, що сприймається як іiі прощання зі світом; згодом вона вип’є «лавро-вишневі» краплі. Намагаючись зберегти свою таємницю, вимушену брехню та зраду, перед кроком в небуття вона турбується про хворого чоловіка, аби йому приклали до голови мокрого рушника.

На розгортання внутрішньопсихологічного конфлікту Наталії Павлівни, що подається у зв'язку 3 ідеями щастя як сенсу й мети людського існування та «чесності з собою», у виставі, як і в драмі В. Винниченка, звертається основна увага. Психологічний портрет героїні — це модель внутрішньої вичерпаності людини (саме тому внутрішня вичерпаність Наталії Павлівни сублімується у зовнішню активність). Варто додати, що мотив внутрішньої вичерпаності персонажа В. Винниченко розвиває і в інших творах — драматичних («Гріх», Закон», Приводженні», «Пророк»), прозових («Федько-халамидник», «Кумедія з Костем», «Бабусин подарунок» та ін.).

У виконанні О. Волошиної Наталія Павлівна — тонка й глибока натура, здатна на самопожертву задля чужого спокою й чужої віри. Ї̈̈ смерть, спровокована брехнею і правдою (дві правди героїні), уводить в дію філософсько-психологічний закон художнього світу В. Винниченка: усе в світі роздвоєне, як і єдине.

Відзначаючи художню багатовимірність твору, С. Михида і М. Вороний наголошують на важливій ролі засобів символізму в поетиці В. Винниченка, зокрема на символіці образів Івана Стратоновича («фігура досить загадкова і незвичайна», «друге я» Наталії Павлівни) та Сані («символ чистоти і справедливості, ідеал, до якого прагне душа головної героїні») (Михида, 2002, с. 90). Можна стверджувати, що символізм у драмі і виставі вбачається в окресленні всіх персонажів.

Отже, у виставі Дніпропетровського українського музично-драматичного театру ім. Т. Г. Шевченка за драмою В. Винниченка «Брехня» режисерська майстерність М. Волошина виявляється передусім у тому, що всі акторські роботи створюють органічний ансамбль, який справляє на глядача потужне враження і приносить естетичну насолоду, у використанні свіжих сценічних форм. Вдалими видаються і сценографія А. Пенковського, виконана в старих добрих традиціях, без модних нині умовностей, і пунктиром проведений музичний супровід (Н. Нусбаум), що органічно вплітається в психологічну атмосферу вистави. Творчий колектив вистави орієнтувався на авторський задум, історико-культурні умови й мистецькі тенденції 1990-х років, що у співдії з індивідуальними художніми рішеннями свідчить про посилену увагу українського театру до проблем основ і сутності життя, брехні і правди, любові і зради, людської гідності і свободи вибору, оновлення його сценічних форм.

Однак у середині 1990-х театр фактично «розійшовся з Винниченком», що, на думку А. Липківської (2012), «доволі красномовно свідчить як про брак кваліфікованих режисерських кадрів, так і про відсутність інтересу до драматургії В. Винниченка у наявного режисерського корпусу» (с. 71). Інтерпретація п'єси «Закон» у Харківському державному українському драматичному театрі ім. Т. Г. Шевченка, прем’єра якої відбулася в 2006 р. у режисурі А. Бакірова, була сприйнята прохолодно.

Постановки драми «Брехня» здійснювали й інші режисери. Так, у 2018 р. відбувся прем'єрний показ вистави режисерки Наталії Сиваненко. 26 жовтня 2006 р. вистава «Брехня» постала на сцені Кримського академічного українського музичного театру, в інтерпретації випускника театрознавчого 


\section{СЦЕНІЧНЕ МИСТЕЦТВО}

ISSN 2410-1176 (Print) • Вісник КНУКіМ. Серія: Мистецтвознавство. Вип. 45 • ISSN 2616-4183 (Online)

факультету Київського інституту театрального мистецтва ім. І. К. Карпенка-Карого Віктора Гуменюка, який у 2001 р. захистив докторську дисертацію «Драматургія Володимира Винниченка. Проблеми поетики».

Критики і рецензенти постановку сприйняли неоднозначно, зокрема С. Пальчинський і О. Біляченко. Очевидно, що С. Пальчинський далеко не об'єктивний у власних судженнях. 3 рецензії помітно, що автора дратує сама «українськість» вистави, використання в ній українських пісень, піднесення української культури. Зважаючи на регіон, де розташований Кримський академічний український музичний театр, можна зрозуміти мотиви С. Пальчинського, але ж це не означає, що вищезгадану рецензію можна називати об'єктивною чи хоча б «гідною критикою». У другому огляді вистави «Брехня» кримського театру стверджувалося, що сценографією, новаторством та образним виділенням надзавдання вистава не вирізняється, музичне оформлення теж не є носієм надзавдання, а колір, світло і весь розмаїтий арсенал сучасних режисерських засобів ігнорується. Безпосередньо режисер постановки В. Гуменюк відповів, що хоча й не вважає свою виставу ідеальною, однак переконливо довів, що зацікавленість та позитивне сприйняття глядачів сценічного дійства налаштовувало режисера на оптимістичний лад і переконало у важливості його особистої роботи та сценічного колективу.

\section{Висновки}

Драматичні твори В. Винниченка, присвячені людській особистості, морально-психологічним випробуванням та внутрішнім силам людини у боротьбі за утвердження власного «я», набули важливого значення зі здобуттям Україною незалежності, адже в них тісно переплелися українська та європейська традиції з новими естетичними віяннями. Найбагатшу сценічну історію з-поміж усіх творів письменника мають п’єси «Чорна Пантера і Білий Ведмідь», «Гріх» та «Брехня».

На початку 1990-х років п’єси В. Винниченка привернули увагу багатьох українських митців. Режисерські втілення подекуди неочікувано дивували. Наприклад, постановка Львівського обласного театру ім. Я. Галана у Дрогобичі «Чорна Пантера і Білий Ведмідь» виявилися далекою від непростих філософських та етичних проблем, якими переймався В. Винниченко. А вистава «Брехня» Київського державного академічного театру драми і комедії на лівому березі Дніпра започаткувала двомовність вистав у театрі. У 2006 р. В. Гуменюк поставив «Брехню» на сцені Кримського академічного українського музичного театру в інтерпретації, яка викликала зацікавленість та позитивне сприйняття глядачів сценічного дійства. Вистава «Гріх» Кіровоградського обласного (нині - академічного) українського музично-драматичного театру ім. М. Л. Кропивницького, на думку режисера М. Горохова, виявила розуміння того, що драматургія В. Винниченка істотно відрізняється від традиційної української драми, вона складна й багатогранна. Під час порівняння вистав Г. Юри і М. Горохова за п’єсою «Гріх» встановлено, що за основу обоє режисерів обрали моральний аспект, виділили три позиції спільного і відмінного різних постанов і різних епох: ціннісні орієнтації — ідеал; позиція — умови — вибір; відповідальність - проступок — кара.

Наголосимо, що найбільш переконливого й цілісного втілення п’єси В. Винниченка набули у постановках А. Бабенко. Режисерка, застосовуючи нововведення у постановці «Чорна Пантера і Білий Ведмідь», надає виставі більшого символізму та створює метафоричний образ швидкоплинності людського життя та вічності мистецтва, а п’єсу «Брехня» насичує духом відродження.

Постановки п’єс В. Винниченка наочно засвідчують, що в українській драматургії і театральному мистецтві зростає особистісне начало, а вистави набувають ознак ідеологічної драми, адже трагічний пафос постає через драму ідей. Сьогодні актуально сприймається нагальна потреба відновлювати історично перевірені обставини й ситуації, висвітлюючи об’єктивні процеси розвитку театрального мистецтва в Україні.

\section{Список використаних джерел}

А. Г. [Головка А.]. (1921а, 20 квітня). «Брехня», п’єса В. Винниченка в 3 діях. Вперед.

А. Г. [Головка А.]. (1921b, 13 жовтня). «Гріх», п’єса В. Винниченка на 3 дії. Виеред.

Бабенко, А. (2004). «Там багато позитивної енергетики» (Інтерв’юер I. Коваль). Кіно-Театр, 1, 9-11.

Босий, П. (б.р.). Спогади про виставу «Гріх». Особистий архів М. Сороки, м. Київ.

Веселка, С. (2003, 11 вересня). Із заньківчанського гнізда. Поступ. 
Веселовська, Г. І. (2010). Украӥнський театральний авангард. Фенікс.

Вечерницький, А. [Кузьмінський О.]. (1911, 4 лютого). «Брехня» В. Винниченка. Рада, 3-4.

Винниченко, В. К. (1991). Вибрані п'єси. Мистецтво.

Вісич, О. А. (2019). Театральний дискурс як основа метадраматизму в п'єсах Володимира Винниченка. Вчені записки Таврійського національного університету імені В. І. Вернадського. Серія: Філологія. Журналістика, $30(1$, ч. 2,), 26-31.

Гринишина, М. (2012). В. Винниченко. «Брехня». В М. О. Гринишина (Ред.), Український театр ХХ століття: Антологія вистав (с. 67-70). Фенікс.

Гузар-Струк, Д. (1994). Винниченкова моральна лабораторія. В В. В. Яременко \& С. В. Федоренко (Упоряд.), Українське слово (Кн. 1; с. 374-384). Рось.

Гуменюк, В. І. (2001). Сила краси: проблеми поетики драматургї Володимира Винниченка. Сімферопольська міська друкарня.

Гурбанська, А. І. (2015). Слово - людина - світ: Студї з літературознавства, культурологї та соиіальних комунікаиій. КОД.

Гурбанська, А. І. (2020, 23 квітня). Володимир Винниченко: драматургія - театр - кіно. В Сценічне мистецтвво: творчі надбання та інноваційні процеси, Матеріали II Всеукраїнської наукової конференції професорськовикладацького складу, докторантів, аспірантів та магістрантів, м. Київ (с. 65-70). Видавничий центр КНУКіМ.

Жулинський, М. (1993). Володимир Винниченко (1880-1951). В В. Г. Дончик (Ред.), Історія української літератури ХХ століття (Кн. 1; с. 481-502). Либідь.

Карась, А. (1992). Откуда взять трагическую развязку. Московский наблюдатель, 11-12, 20.

Ковалів, Ю. І. (2001). Подія та синдром В. Винниченка в українському літературно-культурному світі. Літературознавчі студіï, 1, 119-127.

Костюк, Г. (1980). Володимир Винниченко та його доба. Українська Вільна Академія Наук.

Костюк, Г. (1983). У світі ідей і образів. Вибране. Критичні та історико-літературні роздуми. 1930-1980. Сучасність.

Кравчук, П. (1999). Драматургія В. Винниченка на сцені театру М. Садовського. Украйнський театр, 4, 16-20.

Кравчук, П. (2008). Драматургія Володимира Винниченка у сценічних інтерпретаціях Гната Юри. Вісник Львівського університету. Серія мистеитвознавство, 8, 27-38.

Кьеркегор, С. (1993). Страх и трепет. Республика.

Липківська, А. В. (2012). В. Винниченко. «Брехня». В М. О. Гринишина (Ред.), Украӥнський театр ХХ століття: Антологія вистав (с. 70-76). Фенікс.

Лозинський, М. (1912, 5 березня). «Базар» Винниченка на сцені. Діло, 3-4.

Марко, В. (б.р.). Спогади. Особистий архів А. Гурбанської, Київ.

Михида, С. П. (2002). Слідами його експериментів: Змістові домінанти та поетика конфлікту в драматургї̈ Володимира Винниченка. Центрально-Українське видавництво.

Мороз, Л. 3. (1994). «Сто рівноцінних правд»: Парадокси драматургї̈ В. Винниченка. Інститут літератури ім. Т. Г. Шевченка НАН України.

Панченко, В. (2004). Володимир Винниченко: парадокси долі і творчості. Твім інтер.

Рибалко, П. (2018, 21 червня). До 100-річчя «Гріха» Винниченка. Народне слово, 8.

Селіванова, В. (2001). Мистецтво як культ: інтерпретація драми В. Винниченка «Чорна Пантера і Білий Медвідь» через символ жертвопринесення. Мистецчтвознавство України, 2, 170-174.

Сімович, В. (1911, 9 червня). «Брехня» В. Винниченка. Діло, 3.

Сорока, М. В. (2016). Сценічні інтерпретації драми Винниченка «Гріх» у ХХ ст. Вісник КНУКіМ. Серія: Мистеитввознавство, 35, 50-60.

\section{References}

A. H. [Holovka A.]. (1921a, April 20). "Brekhnia", Piesa V. Vynnychenka v 3 Diiakh [The Lie, a Play by V. Vynnychenko in 3 Acts]. Vpered [in Ukrainian].

A. H. [Holovka A.]. (1921b, October 13). "Hrikh", Piesa V. Vynnychenka na 3 Dii. [The Sin, a Play by V. Vynnychenko in 3 Acts]. Vpered [in Ukrainian].

Babenko, A. (2004). "Tam Bahato Pozytyvnoi Enerhetyky" ["There's a Lot of Positive Energy"] (Interviewer I. Koval). Kino-Teatr [Kino Teatr Magazine], 1, 9-11 [in Ukrainian].

Bosyi, P. (n.d.). Spohady pro Vystavu "Hrikh" [Memories of the Play The Sin]. Personal archive of M. Soroka, Kyiv [in Ukrainian]. 
Hrynyshyna, M. (2012). V. Vynnychenko. "Brekhnia" [V. Vynnychenko. The Lie]. In M. Hrynyshyna (Ed.), Ukrainskyi Teatr XX Stolittia: Antolohiia Vystav [Ukrainian Theatre of the Twentieth Century: An Anthology of Performances] (pp. 67-70). Feniks [in Ukrainian].

Humeniuk, V. (2001). Syla Krasy: Problemy Poetyky Dramaturhii Volodymyra Vynnychenka [The Power of Beauty: Issues of Poetics of Volodymyr Vynnychenko's Drama]. Simferopol city printing house [in Ukrainian].

Hurbanska, A. (2015). Slovo - Liudyna - Svit: Studii z Literaturoznavstva, Kulturolohii ta Sotsialnykh Komunikatsii [Word - Man - World: Literary Studies, Cultural Studies and Social Communications]. KOD [in Ukrainian].

Hurbanska, A. (2020, April 23). Volodymyr Vynnychenko: Dramaturhiia - Teatr - Kino [Volodymyr Vynnychenko: Drama - Theatre - Cinema]. In Stsenichne Mystetstvo: Tvorchi Nadbannia ta Innovatsiini Protsesy [Performing Arts: Creative Achievements and Innovation Processes], Proceedings of the $2^{\text {nd }}$ All-Ukrainian Scientific Conference, Kyiv (pp. 65-70). KNUKIM Publishing [in Ukrainian].

Husar-Struk, D. (1994). Vynnychenkova Moralna Laboratoriia [Vynnychenko's Moral Laboratory]. In V. Yaremenko \& Ye. Fedorenko (Comps.), Ukrainske Slovo [Ukrainian Word] (Vol. 1; pp. 374-384). Ros [in Ukrainian].

Karas, A. (1992). Otkuda Vzyat' Tragicheskuyu Razvyazku [Where to Get the Tragic Denouement]. Moskovskii Nablyudatel' [Moscow Observer,], 11-12, 20 [in Russian].

Kierkegaard, S. (1993). Strakh i Trepet [Fear and Trembling]. Respublika [in Russian].

Kostiuk, H. (1980). Volodymyr Vynnychenko ta Yoho Doba [Volodymyr Vynnychenko and His Time]. Ukrainian Free Academy of Sciences [in Ukrainian].

Kostiuk, H. (1983). U Sviti Idei i Obraziv. Vybrane. Krytychni ta Istoryko-Literaturni Rozdumy. 1930-1980 [In the World of Ideas and Images. Favourites. Critical and Historical-Literary Reflections. 1930-1980]. Suchasnist [in Ukrainian].

Kovaliv, Yu. (2001). Podiia ta Syndrom V. Vynnychenka v Ukrainskomu Literaturno-Kulturnomu Sviti [V. Vynnychenko's Event and Syndrome in the Ukrainian Literary and Cultural World]. Literaturoznavchi Studii [Literary Studies], 1, 119-127 [in Ukrainian].

Kravchuk, P. (1999). Dramaturhiia V. Vynnychenka na Stseni Teatru M. Sadovskoho [V. Vynnychenko's Dramaturgy on the Stage of M. Sadovskyi's Theatre]. Ukrainskyi Teatr [Ukrainian Theater], 4, 16-20 [in Ukrainian].

Kravchuk, P. (2008). Dramaturhiia Volodymyra Vynnychenka u Stsenichnykh Interpretatsiiakh Hnata Yury [Volodymyr Vynnychenko's Dramaturgy in Stage Interpretations by Hnat Yura]. Visnyk Lvivskoho Universytetu. Seriia Mystetstvoznavstvo [Visnyk of the Lviv University. Serie Arts], 8, 27-38 [in Ukrainian].

Lozynskyi, M. (1912, March 5). "Bazar" Vynnychenka na Stseni [Vynnychenko's Bazar on Stage]. Dilo, 3-4 [in Ukrainian].

Lypkivska, A. (2012). V. Vynnychenko. "Brekhnia" [V. Vynnychenko. "The Lie"]. In M. Hrynyshyna (Ed.), Ukrainskyi Teatr XX Stolittia: Antolohiia vystav [Ukrainian Theatre of the Twentieth Century: An Anthology of Performances] (pp. 70-76). Feniks [in Ukrainian].

Marko, V. (n.d.). Spohady [Memoirs]. Personal archive of A. Hurbanska, Kyiv [in Ukrainian].

Moroz, L. (1994). "Sto Rivnotsinnykh Pravd": Paradoksy Dramaturhii V. Vynnychenka ["One Hundred Equal Truths": Paradoxes of V. Vynnychenko's Dramaturgy]. Shevchenko Institute of Literature of the National Academy of Sciences of Ukraine [in Ukrainian].

Mykhyda, S. (2002). Slidamy Yoho Eksperymentiv: Zmistovi Dominanty ta Poetyka Konfliktu v Dramaturhii Volodymyra Vynnychenka [In the Wake of His Experiments: Semantic Dominants and the Poetics of Conflict in the Drama of Volodymyr Vynnychenko]. Tsentralno-Ukrainske vydavnytstvo [in Ukrainian].

Panchenko, V. (2004). Volodymyr Vynnychenko: Paradoksy Doli i Tvorchosti [Volodymyr Vynnychenko: Paradoxes of Destiny and Creativity]. Tvim inter [in Ukrainian].

Rybalko, P. (2018, June 21). Do 100-richchia "Hrikha" Vynnychenka [To the $100^{\text {th }}$ Anniversary of Vynnychenko's The Sin]. Narodne Slovo, 8 [in Ukrainian].

Selivanova, V. (2001). Mystetstvo yak Kult: Interpretatsiia Dramy V. Vynnychenka "Chorna Pantera i Bilyi Medvid" cherez Symvol Zhertvoprynesennia [Art as a Cult: Interpretation of V. Vynnychenko's Drama The Black Panther and the Polar Bear through the Symbol of Sacrifice]. Mystetstvoznavstvo Ukrainy [Art Research of Ukraine], 2, 170-174 [in Ukrainian].

Simovych, V. (1911, June 9). "Brekhnia" V. Vynnychenka [The Lies by V. Vynnychenko]. Dilo, 3 [in Ukrainian].

Soroka, M. (2016). Stsenichni Interpretatsii Dramy Vynnychenka "Hrikh" u XX st. [Stage Interpretations of Vynnychenko's Drama The Sin in the 20th Century]. Visnyk KNUKiM. Seriia: Mystetstvoznavstvo [Bulletin of KNUKiM. Series in Arts], 35, 50-60 [in Ukrainian].

Vechernytskyi, A. [Kuzminskyi O.]. (1911, February 4). "Brekhnia" V. Vynnychenka [The Lies by V. Vynnychenko]. Rada, 3-4 [in Ukrainian].

Veselka, S. (2003, September 11). Iz Zankivchanskoho Hnizda [From the Zankivchansky Nest]. Postup [in Ukrainian]. Veselovska, H. I. (2010). Ukrainskyi Teatralnyi Avanhard [Ukrainian Theatrical Avant-Garde]. Feniks [in Ukrainian]. 
Visych, O. (2019). Teatralnyi Dyskurs yak Osnova Metadramatyzmu v Piesakh Volodymyra Vynnychenka [Theatrical Discourse as a Basis of Metadrama in Plays by Volodymyr Vynnychenko]. Vcheni Zapysky Tavriiskoho Natsionalnoho Universytetu imeni V. I. Vernadskoho. Seriia: Filolohiia. Zhurnalistyka [Scientific Notes of V. I. Vernadsky Taurida National University. Series: Philology. Journalism], 30(1, 2), 26-31 [in Ukrainian].

Vynnychenko, V. (1991). Vybrani Piesy [Selected Plays]. Mystetstvo [in Ukrainian].

Zhulynskyi, M. (1993). Volodymyr Vynnychenko (1880-1951). In V. Donchyk (Ed.), Istoriia Ukrainskoi Literatury XX Stolittia [History of Ukrainian Literature of the Twentieth Century] (Vol. 1; pp. 481-502). Lybid [in Ukrainian].

Стаття надійшла до редакиії: 02.11.2021

\begin{tabular}{|c|c|}
\hline СПЕЦИФИКА & Сорока Марина Васильевна \\
\hline ТЕАТРАЛЬНОЙ ИНСЦЕНИЗАЦИИ & Кандидат искусствоведения, \\
\hline ПРОИЗВЕДЕНИЙ В. ВИННИЧЕНКО & Киевский начиональный университет \\
\hline В КОНЦЕ ХХ - НАЧАЛЕ ХХІ СТ. & $\begin{array}{l}\text { культуры и искусств, } \\
\text { Киев, Украина }\end{array}$ \\
\hline
\end{tabular}

Цель статьи - рассмотреть театральную инсценировку произведений В. Винниченко в украинском театре в конце XX - начале XXI ст. Методология исследования состоит в использовании анализа, синтеза и логического обобщения. В частности, в ходе контент-анализа квантифицировали пьесы В. Винниченко и интерпретировали концептуально-художественные поиски театральных деятелей. Тематический анализ юбилейных публикаций, научных исследований и рецензий на пьесы показал значительное внимание национального театра к проблематике произведений В. Винниченко. Научная новизна заключается в анализе режиссерских воплощений пьес В. Винниченко «Черная Пантера и Белый Медведь», «Грех» и «Ложь» на украинской сцене, а также сравнение спектакля «Грех» разных эпох (Г. Юры и М. Горохова). Выводы. Выяснено, что в начале 90-х годов ХХ века пьесы В. Винниченко привлекали внимание многих украинских художников. В то же время режиссерские воплощения кое-где неожиданно удивляли. Выявлено, что богатую сценическую историю из всех произведений писателя имеют пьесы «Черная Пантера и Белый Медведь», «Грех» и «Ложь». Спектакли Г. Юры и М. Горохова по пьесе «Грех» имеют как сходные черты, так и существенно отличаются. В частности, оба режиссера за основу избрали моральный аспект, в котором выделили три позиции общего и отличного: ценностные ориентации - идеал; позиция - условия - выбор; ответственность - проступок - наказание. Отметим, что наиболее убедительное и целостное воплощение пьесы В. Винниченко приобрели в постановках А. Бабенко. Режиссер, применяя нововведения, насыщает представления символизмом и создает образ быстротечности человеческой жизни и вечности искусства. Доказано, что постановки пьес В. Винниченко наглядно свидетельствуют, что в украинской драматургии и театральном искусстве растет личностное начало, а представления приобретают признаки идеологической драмы. Сегодня актуально воспринимается неотложная потребность восстанавливать исторически правдивые обстоятельства и ситуации, освещая объективные процессы развития театрального искусства в Украине.

Ключевые слова: В. Винниченко; пьесы; режиссер; театр; культура; художественные поиски

\section{THE SPECIAL FEATURES $\mid$ Maryna Soroka OF THE THEATRICAL DRAMATISATION $P h D$ in Art Studies, OF V. VYNNYCHENKO'S WORKS Kyiv National University of Culture and Arts, IN THE LATE $20^{\text {th }}$ AND EARLY $21^{\text {st }}$ Kyiv, Ukraine CENTURIES}

The purpose of the article is to consider the theatrical dramatisation of V. Vynnychenko's works in the Ukrainian theatre in the late $20^{\text {th }}$ - early $21^{\text {st }}$ centuries. The research methodology is based on the use of analysis, synthesis, and logical generalisation. In particular, in the course of content analysis, V. Vynnychenko's plays have been quantified and the conceptual and artistic searches of theatre figures have been interpreted. The thematic analysis of the anniversary-related publications, scientific research, and reviews of plays has shown considerable attention of the Ukrainian theatre to the works of V. Vynnychenko. The scientific novelty consists in analysing the director's staging of V. Vynnychenko's plays The Black Panther and the Polar Bear, The Sin, The Lie on the Ukrainian stage, as well as the comparison of the play The Sin of different eras (H. Yura and 
M. Horokhov). Conclusions. The study shows that in the early 1990s, V. Vynnychenko's plays attracted the attention of many Ukrainian artists. At the same time, sometimes the director's work was unexpectedly surprising. The study demonstrates that the plays The Black Panther and the Polar Bear, The Sin, The Lie have the richest history of all the writer's works. The stage plays by H. Yura and M. Horokhov based on The Sin have both similar features and significant differences. In particular, both directors chose the moral aspect as a basis, in which they singled out three positions of common and different: value orientations - ideal, position — conditions — choice, responsibility — wrongdoing — punishment. It should be noted that the productions of A. Babenko have the most convincing and holistic staging of V. Vynnychenko's plays. The director, applying innovations, saturates the stage plays with symbolism and creates an image of the transience of human life and the eternity of art. It is demonstrated that the productions of V. Vynnychenko's plays clearly show that the identity principle is on the rise in Ukrainian drama and theatre art, and the stage plays are acquiring the signs of an ideological drama. Today, the urgent need to restore historically true circumstances and situations is perceived as relevant, highlighting the objective development processes of theatrical art in Ukraine.

Keywords: V. Vynnychenko; plays; director; theatre; culture; artistic search 